\title{
Environmental Pressure and Armed Conflict - Is there an Empirical Kuznets Curve for Myanmar?
}

Anton Parlow*

Research Fellow, Department of Economics, University of Kaiserslautern, Kaiserslautern, Germany

\begin{abstract}
Empirical Kuznets Curves (EKC) usually implies an inverted U-shaped relationship between a pollutant and per capita GDP growth. We initially find an inverted U-shaped EKC between $\mathrm{CO}_{2}$ emissions and per capita GDP for the period 1960 to 2004. However, once accounting for a major uprising in 1988 in Myanmar, we can identify two different growth regimes. This structural break changes the nature of the EKC relationship.
\end{abstract}

Keywords: Empirical kuznets curve; GDP; Armed conflicts; $\mathrm{CO}_{2}$ emissions

\section{Introduction}

The empirical question if and how GDP growth affects pollution levels has been discussed for more than 20 years. The relationship found most is that there is an inverted U-shaped relationship between a chosen pollutant (e.g. $\mathrm{CO}_{2}$ emissions) and GDP, usually peroxided by per capita income. This inverted U-shaped relationship is known as the empirical Kuznets curve (EKC). The pollution levels of a country can be linked with its level of development. According to the EKC hypothesis countries initially pollute more, e.g. through pollutionintense production technologies, but after reaching a certain level of income, they pollute less. One reason is that consumers are able to demand more environmentally friendly products. Another reason is that with increased trade pollution-intense productions are outsourced to so-called pollution havens [1].

Most studies use a cross-section of countries assuming that these countries have similar developments over time by pooling them. Pooling data masks developments unique to individual countries. However, only a few single country studies are available and estimate country specific Kuznets curves. Out of the single country studies available, none so far tested the role of armed conflict.

Armed conflicts are known to interrupt development processes $[2,3]$. In this context, we test for the existence of an EKC for Myanmar. Myanmar (formerly known as Burma) has been striven by internal conflict since its founding in 1948. The central government has devoted many of its natural resource rents to fund security forces $[4-6]^{1}$. Given these priorities, it is possible that the environment has been given less attention, despite the slow growth in GDP over time.

We initially find that there is an EKC for Myanmar for the period 1960 to 2004. However, this relationship does not hold once accounting for structural breaks. Structural breaks imply that there is a regime shift in the time series, for instance an extreme event in a country. Ignoring a regime shift can bias the results. Myanmar experienced a nationwide uprising in 1988 which was fought down by the central government. Thousands got killed, or imprisoned, a curfew was in place for most of the year and a brain-drain (and brawn-drain) of the youth and educated followed lasting to the present $[7,8]$. This reduction in overall consumption and diversified production can explain why pollution levels went down for Myanmar after the 1988 uprising.

The paper is organized as follows. In section 4 we briefly discuss ${ }^{1}$ For instance, 50 percent of Myanmar's GDP is generated by the production of goods based on natural resources, like teak or water-intense the relevant literature. This is followed by a discussion of empirical methods used in section 5 . The results are discussed in section 4 . The paper concludes in section 6 .

\section{Literature Review}

Starting with the seminal empirical work of Grossman and Krueger [9] a vast amount of research on the EKC relationship has been published ${ }^{2}$.

To conserve space we discuss only a few single country studies in more detail. However, detailed literature reviews can be found in Dinda, Lieb and Stern $[1,10,11]$. Most of the research focuses on a cross-section of countries. Lessons learned from this research are that the EKC relationship depends on the pollutant chosen (e.g. $\mathrm{CO}_{2}, \mathrm{SO}_{2}$, or $\mathrm{NO}_{\mathrm{x}}$ ), and on the econometric techniques used (e.g. OLS, panel estimation techniques) including the transformation of variables. However, data analysis based on a pooled cross-section of countries assumes that countries follow the same development path over time. Individual country experiences can be different. Thus, a few researchers focus on single country studies. These studies include case studies for Sweden [12], Austria [13], China and India [14] and India [15]. These studies choose $\mathrm{CO}_{2}$ emissions as their main pollutant and use ordinary least squares (OLS) or co-integration analysis.

One of the first single country studies was done by Lindmark [12]. He analyzes EKC patterns for Sweden for the period 1870 to 1997 and identifies multiple growth regimes (e.g. the period of industrialization) with each mimicking an inverted U-shaped EKC relationship between $\mathrm{CO}_{2}$ emissions and GDP growth.

\begin{abstract}
${ }^{2}$ The idea that pollution is linked to GDP growth was made popular by Meadows, Meadows, Randers and Behrens 1972 and their report "The limits to growth". Here, they draw a negative picture of the relationship between GDP and pollution. This direct link can be even traced back to early environmentalist / conservationist movement (e.g. Sir William Blake Richmond and his Coal Abatement Pollution Society 1898, or Rachel Carson and her book "Silent Spring" 1962). However, the EKC relationship implies that pollution levels eventually decrease with more economic development.
\end{abstract}

*Corresponding author: Anton Parlow, Research Fellow, Department of Economics, University of Kaiserslautern, Kaiserslautern, Germany, Tel: +49 (0) 631 205 3766; E-mail: anton.parlow@wiwi.uni-kl.de

Received March 11, 2014; Accepted April 15, 2014; Published April 22, 2014

Citation: Parlow A (2014) Environmental Pressure and Armed Conflict - Is there an Empirical Kuznets Curve for Myanmar? J Glob Econ 2: 111. doi:10.4172/23754389.1000111

Copyright: (c) 2014 Parlow A. This is an open-access article distributed under the terms of the Creative Commons Attribution License, which permits unrestricted use, distribution, and reproduction in any medium, provided the original author and source are credited. 
Citation: Parlow A (2014) Environmental Pressure and Armed Conflict - Is there an Empirical Kuznets Curve for Myanmar? J Glob Econ 2: 111. doi:10.4172/2375-4389.1000111

Friedl and Getzner [13] find that for Austria an N-shaped EKC fits their data the most. They cover the period 1960 to 1999 and identify a structural break in 1975. Austria opened up to more trade in 1975 and experienced a period of rapid growth thereafter. Accounting for the structural break changes the nature of the EKC relationship from linear to a cubic relationship.

Studies for developing countries mostly focus on China or India. Jayanthakumaran et al. [14] compare the EKC paths of China and India for the period 1971-2007. Both countries have experienced rapid phases of growth. It can be argued that at least initially the pressure on the environment was ignored by the governments. They find that an inverted U-shaped EKC does exist for both countries. Furthermore, structural breaks can be identified for China. However, these structural breaks do not alter the nature of the EKC relationship. These regime changes can be explained by economic reforms in the 1980s and 1990s $[16]^{3}$.

While Jayanthakumaran et al. [14] do not find a significant structural break for India, Kanjilal and Gosh [15] find a significant structural break for India in 1991. India experienced an economic crisis early in the 1990s and introduced many reforms to liberalize the Indian economy. They find an inverted U-shaped EKC for the period before 1991. However, for the period after 1991 they find that there is no relationship between per capita income and $\mathrm{CO}_{2}$-emissions.

These studies show that ignoring structural breaks can potentially lead to wrong conclusions about the EKC relationship between GDP and $\mathrm{CO}_{2}$ emissions. While the above regime changes are mainly explained by economic pressure, the role of internal armed conflict has not been studied yet. Thus, the case of Myanmar can be helpful in understanding other determinants of structural breaks in EKC relationships.

\section{Empirical Strategy}

Our data come from the World Bank [17] and cover the period 1960 to 2004. Given the internal armed conflict in Myanmar most time series are interrupted, or not reported (e.g. PM-10, PFC, SO4 and other greenhouse gases), and limit the scope of our analysis. However, $\mathrm{CO}_{2}$ emissions, as one of the main pollutants used, and GDP per capita are available for the entire period $[18]^{4}$.

Our simple empirical model takes following form:

$$
c o_{2}=\alpha+\beta_{1} Y_{t}+\beta_{2} Y_{t}^{2}+\sum_{j=1}^{n=2} \beta_{j} X_{j t}+\tau+\epsilon_{t}
$$

$\mathrm{CO}_{2}$ emissions are measured in metric per capita tons. (To follow a consumption based approach as suggested by Rothman [19], we decompose overall $\mathrm{CO}_{2}$ emissions into emissions based on gas fuel consumption, liquid fuel consumption and solid fuel consumption. $\mathrm{Y}$ is per capita income measured in constant LCU. The vector X contains measurements for trade openness and for the level of urbanization. Trade openness is used to test for the pollution haven hypothesis. We use the level of urbanization to explain where consumption of different fuel types can take place. For instance, it is more likely that people use

${ }^{3}$ Note, that these results are limited to the period 1970 onwards. Especially during the "Great Leap Forward" in the 1960s China's pollution levels increased rapidly. However, given the low level of industrialization before 1957 in China, moving the starting point of the EKC to this period should not change the nature of the inverted U-shaped EKC found by others.

${ }^{4} \mathrm{~A}$ general concern with data from less developed countries is that the national reporting agencies sometimes cannot produce reliable data, especially in situations of conflict. However, the World Bank (or Asian Development Bank) monitors and supports national agencies in data collection and reporting. Furthermore, the Central Statistical Organization in Myanmar is committed to improve their reporting system. more cars, or natural gas heaters, in urban settings. The parameter $\mathrm{T}$ is a linear trend. The parameter $\epsilon$ is the usual error-term.

The EKC hypothesis states that there can be an inverted U-shaped relationship between $\mathrm{CO}_{2}$ emissions and GDP per capita. Figure 1 illustrates this relationship. Initially, countries pollute more with increasing levels of GDP per capita, and once reaching a turning point, countries pollute less with increasing levels of GDP per capita. This implies the following signs of the model coefficients: $\beta 1>0$ and $\beta 2<0$. These signs can be tested by a simple t-test. Furthermore, both coefficients have to be jointly significantly different from zero for the inverted U-shaped ECK hypothesis to hold. This can be tested by an F-test.

To test for structural breaks we employ a Chow-test [20]. A Chow-test tests for the significance of a known break in the time series. To identify a break in our time series we plot the four different measurements of $\mathrm{CO}_{2}$ emissions over time Figure 2. A break can be identified in 1988 . Myanmar experienced an uprising in 1988 which was fought down by the central government with military force ${ }^{5}$. Emission levels fell rapidly ${ }^{5}$ This is known as the 8888 -uprising because the uprising took place on August 8th. 1988

Pollutant/Emissions

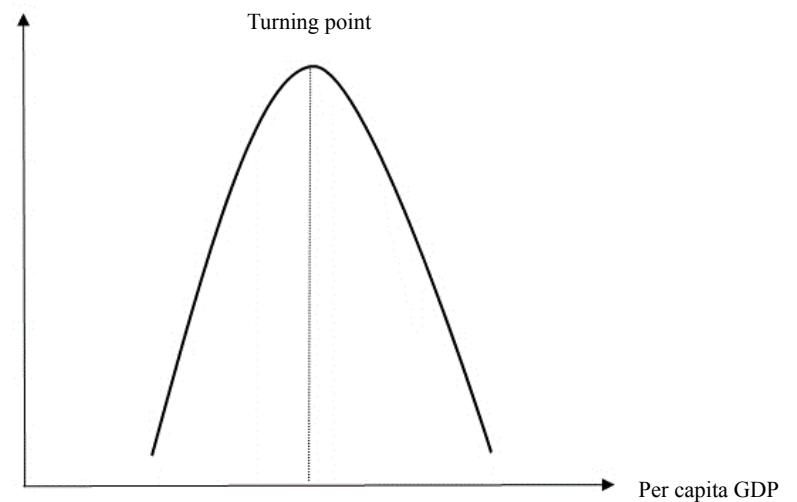

Increasing leval of development

Figure 1: A stylized EKC

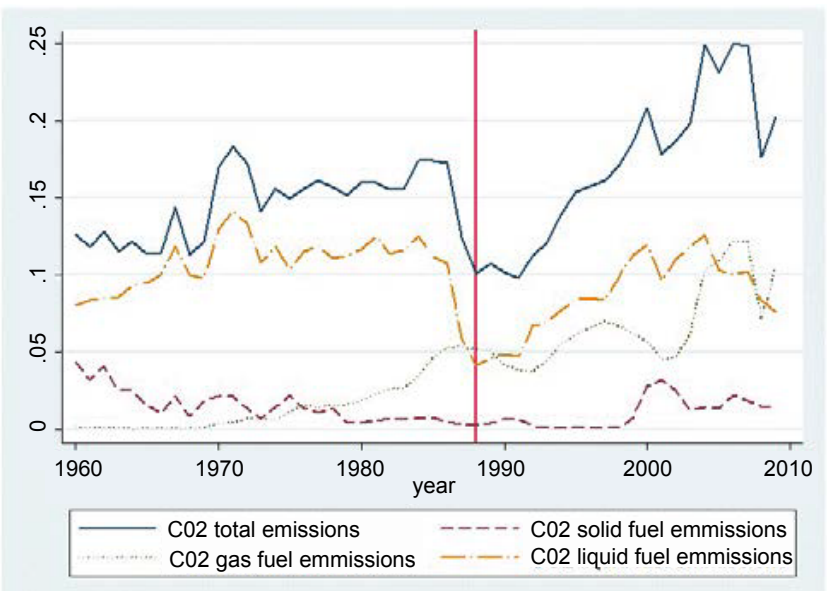

in per capita metric tons (mt). Based on World Bank (2013) data.

Figure 2: Trends in $\mathrm{CO}_{2}$ emissions - 1960 - 2010. 
Citation: Parlow A (2014) Environmental Pressure and Armed Conflict - Is there an Empirical Kuznets Curve for Myanmar? J Glob Econ 2: 111. doi:10.4172/2375-4389.1000111

Page 3 of 6

after the uprising. This can be mainly explained by a reduction in fuel consumption because of the thousands of people killed, or imprisoned, an imposed curfew and the migration of thousands of people.

Thus the above model includes a variable indicating the structural break $\left(\mathrm{D}_{1988}\right)$ :

$$
c o_{2}=\alpha+\beta_{1} Y_{t}+\beta_{2} Y_{t}^{2}+\sum_{j=1}^{n=2} \beta_{j} X_{j t}+D_{1988}+\tau+\epsilon_{t}
$$

In the case of a significant structural break we2split the samples in a period before and after the uprising.

\section{Results}

\section{Simple regressions}

Before turning to our empirical results, we plot $\mathrm{CO}_{2}$ emissions and per capita GDP to take an initial look at the relationship between the two variables Figure 3. We present graphs for overall emissions and distinguish emissions based on type of fuel consumption [17]. Fuel consumption can be differentiated by the consumption of solid fuels (e.g. coal or fuel woods), liquid fuels (e.g. petroleum) and gas fuels (e.g.
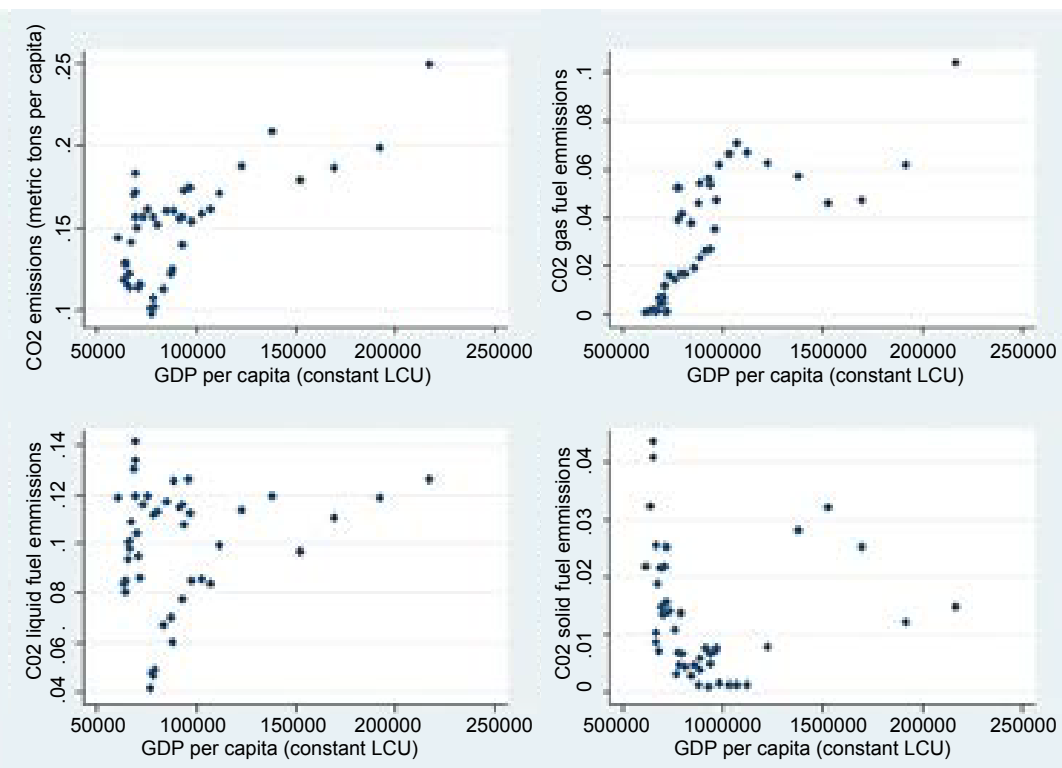

$\mathrm{CO}_{2}$ emissions are in per capitita metrric tons (mt) and per capita Income in ccnstant LCU.Based on World Bank (2013) data.

Figure 3: $\mathrm{CO}_{2}$ emissions and per capita income - $1960-2004$
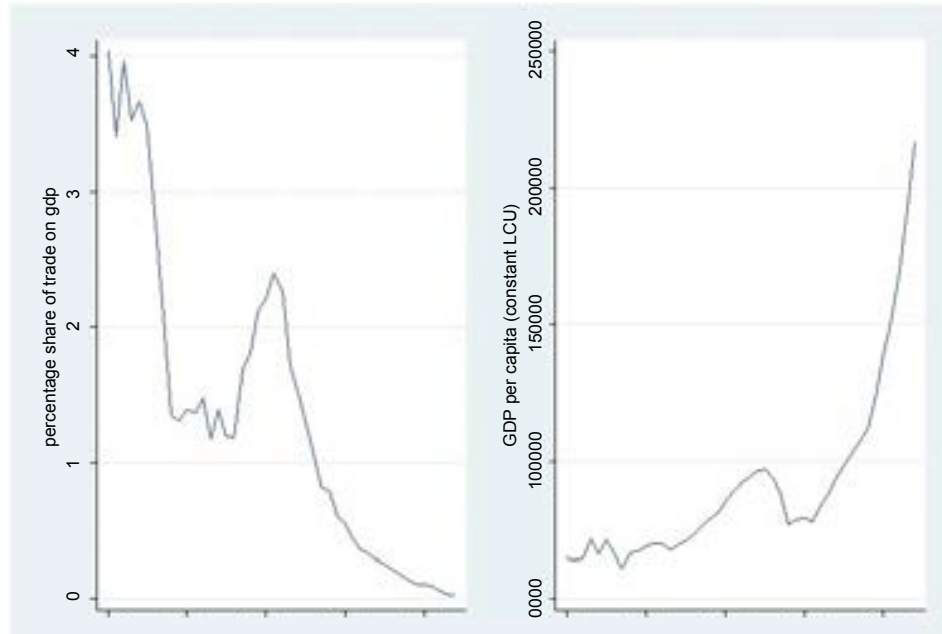

Based on World Bank (2013) data

Figure 4: Trade as share of GDP and GDP per capita - 1960 to 2004. 
natural gas). It is possible to identify inverted U-shaped EKCs for most fuel types. However, there is a concentration of $\mathrm{CO}_{2}$ emissions at low levels of per capita GDP. This could be explained by a structural break in our series and deserves more attention later. Furthermore, for an inverted U-shaped EKC to exist per capita GDP has to increase over time. Per capita GDP is indeed slowly increasing for our time period Figure 4.

We present results for a baseline model and a model including additional control variables in Table 1 . We find some evidence that there is an inverted U-shaped EKC for Myanmar. The coefficient of per capita GDP $\left(\mathrm{Y}_{\mathrm{t}}\right)$ is positive and significant at the $5 \%$ level. The second derivative of per capita GDP $\left(Y_{t}^{2}\right)$ has the expected negative sign and is significant as well. This EKC relationship can mainly be explained by the consumption of liquid fuels, e.g. the use of petroleum for cars. This shows that differentiating $\mathrm{CO}_{2}$ emissions by type of fuel consumption can enhance the understanding of the origin of the EKC relationship.

Adding control variables does not alter the underlying EKC relationship and improves the model fit. Trade openness itself has no significant effect on emission levels. Given that trade only plays a minor role for Myanmar's economy after the former socialist government took over in 1962 this finding is not un-expected (Figure 4). Urbanization itself has the expected positive effect on $\mathrm{CO}_{2}$ emissions. Most consumption, especially the consumption of liquid fuels, takes place in urban settings.

We find some evidence for an inverted U-shaped EKC for Myanmar. However, while interpreting the results, it should be kept in mind that accounting for the 1988 uprising could alter this relationship.

\section{Structural break regressions}

In Table 2 we present the results for the models including structural breaks. Our hypothesis is that the 1988 uprising changed the development path of Myanmar. If the structural break is significant (Chow-test) we can conclude that the period before 1988 is different from the period after 1988. We find for most of our $\mathrm{CO}_{2}$ emission measurements a significant structural break. We split the sample into two periods (1960 to 1987, and 1988 to 2004). Accounting for the structural break also changes the nature of the EKC relationship. The former inverted U-relationship is not supported by the data anymore.

We find a negative effect of per capita GDP on $\mathrm{CO}_{2}$ emissions for the period before 1988. This can be explained by a change in composition of economic activities in Myanmar. A major part of economic activities during the 1960s was the mineral industry including the refining of oil for the export market. These types of industries are also heavy polluters. The socialist government at this time decided to close the country for trade [21]. This can be seen by the sharp decrease in trade Figure 4. However, the reduced export activities led to less mining and refining activities and therefore to economic activities actually reducing $\mathrm{CO}_{2}$ emissions.

However, after 1988 the new military government opened up the economy not just for trade, but also to private enterprises, GDP growth started to increase rapidly. With this $\mathrm{CO}_{2}$ emissions increased again. We can find some evidence that for the post 1988 period the EKC relationship changes to an inverted U-shaped EKC relationship.

Overall, comparing the period 1960 to 1987 and 1988 to 2004 it could be argued that the EKC relationships shows tendencies for an $\mathrm{N}$-shaped EKC curve. This kind of relationship implies that economies initially pollute with GDP growth, then emissions peak, fall and reach a minimum, and start to grow again. Especially, before 1960 Myanmar (or Burma) was one of the flourishing economies in South Asia, which means that our data could pick up the second part of an inverted U-shaped EKC for the period before 1988 .

\section{Conclusions}

This paper used survey data for the Argentinean, Brazilian and Uruguayan foreign exchange rate markets and tested for expectation unbiasedness. Given that the Uruguayan and Argentinean Peso, and the Brazilian Real were floated - to different extents, around the beginning of the 2000s, and that the three countries have exhibited relatively low levels of inflation since then, it is interesting to test for expectation failures in the three markets and investigate whether some pattern can be extracted.

Empirical Kuznets Curves (EKC) has been in the focus of research for more than 20 years. However, most studies use a cross section of countries and therefore could ignore developments unique to individual countries. The few single country studies available focus on developed countries, or on developing countries like China and India. Here, we test for an inverted U-shaped EKC relationship between $\mathrm{CO}_{2}$ emissions and per capita GDP for Myanmar. Myanmar is one of the

\begin{tabular}{|c|c|c|c|c|c|c|c|c|}
\hline $\begin{array}{l}\mathrm{CO}_{2} \text { emmissions per } \\
\text { capita in kt }\end{array}$ & total & & gas fuel & & liquid fuel & & solid fuel & \\
\hline \multirow[b]{2}{*}{$Y_{t} \times 10^{-6}$} & $0.248^{\star *}$ & $0.279^{\star *}$ & -0.0551 & -0.0596 & $0.254^{\star \star \star}$ & $0.282^{\star \star \star}$ & 0.0644 & $0.0851^{*}$ \\
\hline & $(0.0948)$ & $(0.111)$ & $(0.0548)$ & $(0.0635)$ & $(0.0813)$ & $(0.0809)$ & $(0.386)$ & (0.479) \\
\hline \multirow[b]{2}{*}{$Y_{t}^{2} \times 10^{-10}$} & $-0.00548^{*}$ & $-0.00765^{\star *}$ & 0.00208 & 0.00276 & $-0.00669^{* *}$ & $-0.00904^{* * *}$ & -0.00128 & -0.00165 \\
\hline & $(.00318)$ & $(0.00199)$ & $(0.00254)$ & $(0.00219)$ & $(0.00126)$ & $(0.00263)$ & $(0.00126)$ & $(0.00149)$ \\
\hline \multirow[t]{2}{*}{ Trade } & & .0138805 & & -.0188911 & & .033315 & & -.0397278 \\
\hline & & $(.0724913)$ & & $(.0203634)$ & & $(.0447428)$ & & $(.0328332)$ \\
\hline \multirow[t]{2}{*}{ Urban } & & $2.326116^{\star * *}$ & & $-1.023762^{\star * *}$ & & $2.905762^{* \star *}$ & & $-.4687254^{*}$ \\
\hline & & $(.411279)$ & & $(.161561)$ & & $(.3268827)$ & & $(.2450822)$ \\
\hline Trend & yes & yes & yes & yes & yes & yes & yes & yes \\
\hline Constant & yes & yes & yes & yes & yes & yes & yes & yes \\
\hline $\mathbf{N}$ & 45 & 45 & 45 & 45 & 45 & 45 & 45 & 45 \\
\hline $\mathbf{R}^{2}$ & 0.58 & 0.75 & 0.86 & 0.91 & 0.34 & 0.76 & 0.51 & 0.54 \\
\hline F-test & $0.0125^{\star *}$ & $0.0159^{* *}$ & 0.3209 & 0.3539 & $0.0033^{* * *}$ & $0.0012^{* * *}$ & 0.103 & $0.08^{*}$ \\
\hline
\end{tabular}

Note: Significant at ${ }^{* * *} 1 \%,{ }^{* *} 5 \%,{ }^{*} 10 \%$. Robust standard errors are in parentheses and the adjusted R2 is reported.

Table 1: Simple empirical Kuznets Curves - 1960 to 2004. 
Citation: Parlow A (2014) Environmental Pressure and Armed Conflict - Is there an Empirical Kuznets Curve for Myanmar? J Glob Econ 2: 111. doi:10.4172/2375-4389.1000111

Page 5 of 6

\begin{tabular}{|c|c|c|c|c|}
\hline $\mathrm{CO}_{2}$ emmissions per capita in kt & total & gas fuel & liquid fuel & solid fuel \\
\hline \multicolumn{5}{|c|}{ First period 1960-1987 } \\
\hline \multirow{2}{*}{$Y_{t} \times 10^{-6}$} & $-.0000122^{* * *}$ & 0.169 & -0.195 & $-.0000142^{* * *}$ \\
\hline & -0.418 & -0.106 & -0.206 & -0.339 \\
\hline \multirow{2}{*}{$Y_{t}^{2} \times 10^{-8}$} & $0.000844^{* * *}$ & $-0.000121^{*}$ & 0.0000998 & $0.00102^{* * *}$ \\
\hline & $(0.0002 .42)$ & -0.000069 & -0.000114 & -0.000195 \\
\hline \multirow[t]{2}{*}{ Trade } & 0.0578228 & $-.0564^{\star * *}$ & 0.0173 & 0.0791 \\
\hline & -0.088714 & -0.0159 & -0.0317 & -0.0478 \\
\hline \multirow[t]{2}{*}{ Urban } & $2.937475^{\star * *}$ & $-1.658^{* * *}$ & -0.3553 & $4.362^{* * *}$ \\
\hline & -0.802859 & -0.1508 & -0.219 & -0.4636 \\
\hline Trend & yes & yes & yes & yes \\
\hline Constant & yes & yes & yes & yes \\
\hline $\mathbf{N}$ & 28 & 28 & 28 & 28 \\
\hline $\mathbf{R}^{2}$ & 0.61 & 0.97 & 0.7 & 0.77 \\
\hline \multirow[t]{2}{*}{ Break in 1988} & $-.0386^{\star * *}$ & -0.0111345 & $.0169^{* * *}$ & $-.0394^{* * *}$ \\
\hline & -0.012 & -0.0067 & -0.0059 & -0.0087 \\
\hline Chow-test P-value & $0.0046^{* * *}$ & 0.1074 & $0.0071^{* * *}$ & $0.0001^{* * *}$ \\
\hline \multicolumn{5}{|c|}{ Second Period 1988-2004 } \\
\hline \multirow{2}{*}{$Y_{t} \times 10^{-6}$} & -0.212 & $-0.540^{\star *}$ & $0.305^{*}$ & 0.0151 \\
\hline & -0.25 & -0.195 & -0.144 & -0.159 \\
\hline \multirow{2}{*}{$Y_{t}^{2} \times 10^{-8}$} & 0.0000784 & $0000157^{* * *}$ & $-0.0000784^{* *}$ & 0.000000208 \\
\hline & -0.0000617 & -0.0000472 & -0.0000319 & -0.0000354 \\
\hline \multirow[t]{2}{*}{ Trade } & $2.73489^{* *}$ & $2.815^{\star *}$ & -0.3301 & 0.2751 \\
\hline & -1.066543 & -0.9304 & -0.524 & -0.5221 \\
\hline \multirow[t]{2}{*}{ Urban } & $-10.11034^{*}$ & -7.05 & 0.094 & -2.7046 \\
\hline & -5.454799 & -4.312 & -3.278 & -3.5033 \\
\hline Trend & yes & yes & yes & yes \\
\hline Constant & yes & yes & yes & yes \\
\hline $\mathbf{N}$ & 17 & 17 & 17 & 17 \\
\hline $\mathbf{R}^{2}$ & 0.94 & 0.75 & 0.68 & 0.94 \\
\hline
\end{tabular}

Table 2: Structural breaks regressions - 1960 to 2004

least developed countries in South Asia and experienced internal armed conflict since its independence in 1948. The low level of development and the experience of armed conflict could potentially change the EKC relationship.

We initially find an inverted U-shaped EKC for the period 1960 to 2004. However, once accounting for the 1988 uprising we can identify two different growth regimes because of the structural break in 1988 . Structural breaks are usually explained by economic pressures (e.g. a recession) or economic reforms. The role of armed conflict has not been studied yet and adds another possible channel for a structural break in a country's development path.

We find that $\mathrm{CO}_{2}$ emissions are decreasing with slow per capita GDP growth for the period before 1988. This can be mainly explained by a change in composition in Myanmar's economy from export industries based on heavy polluting mineral refining to less polluting agriculture. The period after 1988 shows rapid growth because of policy changes initiated by the new government. This period could potentially lead to an inverted U-shaped EKC kind of development, especially given recent market-based economic reforms under their Sein government in the country [22] and the problem of growing air pollution in Myanmar $[23]^{6}$.

${ }^{6}$ Note, the increased pollution levels could possibly also be explained by the use of less environmentally friendly technologies. Especially, the brain-drain after the 1988 uprising could have lead to less research and development activities and less innovation in production and therefore less environmentally friendly technologies.

\section{References}

1. Dinda S (2004) Environmental Kuznets Curve Hypothesis: A Survey, Ecol Econ 49: 431-455.

2. Collier P, Anke H (1998) On Economic causes of civil war, Oxford Econ Pap, 50: 653-573.

3. Miguel E, Satyanath S, Sergenti E (2004) Economic Shocks and Civil Conflict An Instrumental Variables Approach, J Polit Econ, 112: 725-753.

4. Mya M (1989) The Burma road to poverty: A socio-political analysis, The Fletcher Forum of World Affairs 13: 271-294.

5. South A (2011) Burma's Longest War - Anatomy of the Karen Conflict.

6. Kyi KM, Findlay R, Sundrum RM, Maung M, Nyunt M, et al. (2000) Economic Development of Burma, Singapore University Press Ltd.

7. Thu MC (2008) Burma's Brawn and Brain Drain, The Irrawaddy.

8. Naing ST (2012) Popular education, cross-border civil society and possibilities for democracy in Burma, Sidney, Australia.

9. Grossman GM, Krueger AB (1991) Environmental Impacts of a North American Free Trade Agreement, NBER Working Paper No.3914.

10. Lieb CM (2003) The Environmental Kuznets Curve - A Survey of the Empirical Evidence and of Possible Causes, University of Heidelberg, Discussion Paper Series No.391.

11. Stern DI (2004) The Rise and Fall of the Environmental Kuznets Curve, World Development 32: 1419-1439.

12. Lindmark M (2002) An EKC-pattern in historical perspective: carbon dioxide emissions, technology, fuel prices and growth in Sweden 1870-1997, Ecol Econ 42: 333-347. 
Citation: Parlow A (2014) Environmental Pressure and Armed Conflict - Is there an Empirical Kuznets Curve for Myanmar? J Glob Econ 2: 111. doi:10.4172/2375-4389.1000111

Page 6 of 6

13. Friedl B, Getzner M (2003) Determinants of CO2 emissions in a small open economy, Ecol Econ 45: 133-148.

14. Jayanthakumaran K, Verma R, Liu Y (2012) CO2 emissions, energy consumption, trade and income: A comparative analysis of China and India, Energ Policy 42: 450-460.

15. Kakali K, Sajal G (2013) Environmental Kuznet's curve for India: Evidence from tests for cointegration with unknown structural breaks, Energ Policy 56: 509515

16. Dikoetter F (2010) Mao's Great Famine: The History of China's Most Devastating Catastrophe, 1958-62, Bloomsbury Publishing, London, UK.

17. World Bank (2013) World Development Indicators 1960 to 2012.
18. Tin US (2003) Myanmar Statistical System, Central Statistical Organization, Myanmar.

19. Rothman DS (1998) Environmental Kuznets curves - real progress or passing the buck? A case for consumption-based approaches, Ecol Econ, 25: 177-194.

20. Chow GC (1960) Tests of Equality between Sets of Coefficients in Two Linear Regressions, Econometrica 28: 591-605.

21. Tin SOE (2008) Policy Dilemmas and Economic Development: A Case Study of Myanmar Economy in Transition, 15: 1-30.

22. Lex R (2012) The Myanmar Economy: Tough Choices.

23. Myint SYS (2012) Our growing air pollution problem, The Myanmar Times 31 614. 